\title{
Mit adHATNAK a TÁRSADALMi VÁLLALKOZÁSOK A FELSŐOKTATÁSNAK? - PerspeKtívÁK ÉS KAPCSOLÓDÁSOK
}

\author{
MATOLAY RÉKA ${ }^{a, *}$ - RÉVÉSZ ÉVA ERIKA \\ ${ }^{a}$ Budapesti Corvinus Egyetem, Vállalatgazdaságtan Intézet, Döntéselmélet Tanszék \\ ${ }^{\mathrm{b}}$ Budapesti Corvinus Egyetem, Vezetéstudományi Intézet, Vezetés és Kontroll Tanszék
}

Cikkünkben a társadalmi vállalkozások és a felsőoktatás lehetséges kapcsolatát, kapcsolódásait járjuk körül elsősorban abból a szempontból, hogy a társadalmi vállalkozás viszonylag új koncepciója miképp hathat a felsőoktatási intézmények müködésére. Ezt a kérdést - a társadalmi vállalkozás fogalmának körbejárását követően - három irányból látjuk izgalmasnak vizsgálni: elsőként bemutatjuk a társadalmi vállalkozás koncepció néhány lehetséges hatását a felsőoktatási intézmények müködésére; ezt követően a tématerület megjelenését tekintjük át a felsőoktatásban, fókuszálva a gazdálkodástudományok területére; végezetül elemezzük a társadalmi vállalkozásokhoz való kapcsolódást egy úgynevezett science shop tapasztalatai alapján, amelyet a felsőoktatási intézmények harmadik missziójának egyik megvalósítási módjaként tartanak számon.

Kulcsszavak: társadalmi vállalkozás, felsőoktatási intézmények, harmadik misszió, science shop

In this article, we examine the potential relationships between social enterprises and higher education (HE), primarily in terms of how the relatively new concept of social enterprise may affect the operation of higher education institutions. After exploring the concept of social enterprise / social entrepreneurship, we look at this issue in three ways: first, 1) we describe potential effects of the concept of social enterprise on the operation of HE institutions; then 2) we review the appearance of the topic in higher education, focusing on the field of business administration, and finally 3) we analyze the connection to social enterprises based on the experience of a science shop, which is considered a way of accomplishing the third mission of HE institutions.

Keywords: social enterprise, social entrepreneurship, higher education institutions, third mission, science shop

* Levelező szerző: Matolay Réka, Budapesti Corvinus Egyetem, 1093 Budapest, Fővám tér 8.

E-mail: reka.matolay@uni-corvinus.hu 


\section{Bevezetés}

A társadalmi vállalkozás (social entrepreneurship / social enterprise) olyan tevékenység/szervezet, amely társadalmi célokat és gazdasági-üzleti tevékenységeket együttesen valósít meg. E lényegre törő és rövid meghatározás mögött ugyanakkor a társadalmi vállalkozásoknak számos közelítésmódja bontakozik ki. Ezekbe nyújt cikkünk első része betekintést nem csupán e relatívan új fogalom megismertetése céljával, hanem azzal a definíciós szelekcióval, amely véleményünk szerint a felsőoktatáshoz való kapcsolódás kifejtését jól szolgálja.

Mind a társadalmi vállalkozások, mind a felsőoktatási intézmények hibrid szervezeteknek tekinthetők abban az értelemben, hogy nem sorolhatók be egyértelmüen a klasszikus három szektor - üzleti, nonprofit és közszféra - egyikébe sem, hanem szektorhatáron elhelyezkedő, több szektor jellemzőivel is leírható intézmények. A hibrid működést a felsőoktatási intézmények esetében erősíti, hogy az utóbbi években az egyetemekkel szemben egyre erőteljesebb elvárásként jelenik meg a társadalmi hatásuk növelése. Cikkünkben azt a kérdést járjuk körül, hogy a társadalmi vállalkozás koncepció hogyan jelenik meg az egyetemek müködésében, és mit adhatnak a társadalmi vállalkozások a felsőoktatásnak.

A társadalmi vállalkozás és felsőoktatás kapcsolódását több rétegen keresztül mutatjuk be. Elsőként a felsőoktatási intézmények működtetése szemszögéből tekintünk a társadalmi vállalkozásokra - vajon ez a filozófia és gyakorlat lehet-e felsőoktatási intézmény működési kerete, annak egésze, illetve elemei hol adhatnak jól teret társadalmi vállalkozási kapcsolatoknak?

Másrészt mint oktatott témát vizsgáljuk a kapcsolódás lehetőségeit: azt ahogy a társadalmi vállalkozások megjelennek tantárgyakban elsősorban a gazdálkodástudományi egyetemi képzésekben, s ezzel új terepre kalauzolják a hallgatókat. Alkalmasint a témával együtt oktatásmódszertani újítások is kerülnek felsőoktatási intézményekbe, egyes kurzusoknál pedig az a szándék is felmerül, hogy kritikai nézőpontot szolgáltasson a fóáramú üzleti-gazdasági oktatás üzeneteihez.

Végezetül egy következő réteget azáltal fejtünk fel, hogy bemutatjuk az úgynevezett science shop koncepciót, amely - többek között - társadalmi vállalkozások előtt kívánja megnyitni az egyetemet oly módon, hogy e szervezetek a kérdéseikre az egyetemi oktatási-kutatási folyamatok keretében diákoktól és oktatóktól-kutatóktól közvetlenül választ kapjanak. Ezáltal a társadalmi vállalkozásokkal való kapcsolatot a kurzusok, szakdolgozatok, egyéb kutatások szélesebb körébe ágyazza.

\section{Mit értünk társadalmi vállalkozás alatt?}

A társadalmi vállalkozás fogalma az 1990-es évek elején terjedt el az Egyesült Államokban és Nyugat-Európa számos országában (Defourny-Nyssens 2012). Közép-KeletEurópában valamivel később, a 2000-es évek elején jelent meg a kifejezés, hazánkban elsősorban nemzetközi fejlesztő és támogató szervezetek tevékenységének eredményeképp lett ismert (Kiss-Mihály 2019). Az Ashoka (www.ashoka.org) 1995-ben, a NESsT (www.nesst.org) 2001-ben kezdte meg működését Magyarországon. Mindkét szervezet 
a társadalmi vállalkozás (social entrepreneurship) terminust használva támogatta az ilyen jellegü kezdeményezéseket, ezáltal fontos szerepet játszottak a koncepció ismertté válásában.

Bár az elmúlt évtizedekben a társadalmi vállalkozások számának és a fogalom ismertségének növekedésével e területtel foglalkozó kutatók és kutatások száma is növekedett, a társadalmi vállalkozásoknak nincs széles körben elfogadott meghatározása a szakirodalomban, sokféle irányzat, nézőpont létezik (Defourny-Nyssens 2016). Az egyes megközelítéseknek ugyan számos hasonló eleme van, ám ezek a definíciók meglehetősen különböző vonásait hangsúlyozzák a koncepciónak. Az Ashoka meghatározásában „a társadalmi vállalkozók a társadalom legsürgetőbb társadalmi, kulturális és környezeti kihívásaira adott innovatív megoldásokkal rendelkező személyek. Ambiciózusak és kitartóak - fontos ügyeket oldanak meg, és új ötleteket adnak rendszerszintü változásokra" (www.ashoka.org/en/focus/social-entrepreneurship, fordítás: Kiss-Mihály, 2019: 26). Az Ashoka megközelítése a változásokra és a társadalmi innovációra fókuszáló társadalmi vállalkozók szerepét emeli ki. A NESsT értelmezésében a társadalmi vállalkozás „tudatosan tervezett és működtetett vállalkozói tevékenység, ami társadalmi problémák innovatív megoldására jött létre. Kettős cél vezérli: egyszerre célozzák a pénzügyi fenntarthatóságot és a jelentős társadalmi hatás elérését, mindezt jó minőségű termékek és szolgáltatások folyamatos és felelős módon történő értékesítésén keresztül érik el" (Tótb-Varga-Varga 2011: 5). Ebben a definícióban a társadalmi hatás elérésének célja mellett ugyanolyan fontossággal jelenik meg a pénzügyi életképességet biztosító vállalkozói tevékenység.

Nyugat-Európában a tématerület iránt az 1990-es évek második felében erősödött meg a tudományos érdeklődés, ekkortájt indították az első egyetemi kutatási és képzési programokat (Kiss 2015). Nemzetközi kutatói hálózatok jöttek létre, ezek közül kiemelendő az EMES Kutatóhálózat (emes.net), amelyet 1996-ban alapítottak a társadalmi vállalkozások kutatása céljából. Az EMES Kutatóhálózat három kategória mentén ragadja meg a társadalmi vállalkozások fontosabb jellemzőit, így az alábbi kilenc elemü kritériumrendszer alapján határozzák meg a vizsgált szervezeti kört (Defourny-Nyssens, 2012):

- Gazdasági és vállalkozási dimenzió: 1) a termékelőállítás és/vagy szolgáltatásnyújtás folyamatos (nem csupán időszakos) tevékenysége a szervezetnek; 2) gazdasági kockázatvállalás jellemzi; 3) fizetett munkaerőt (is) foglalkoztat, azaz nem kizárólag önkéntesekkel dolgozik;

- Társadalmi dimenzió: 4) fó cél a közösség szolgálata; 5) alulról jövő kezdeményezés eredményeképp jött létre; 6) a társadalmi cél elsődlegessége miatt korlátozott profitszétosztás jellemzi;

- Részvételi irányítás dimenzió: 7) magas szintü autonómia; 8) döntéshozói hatalom nem függ a birtokolt tőkerésztől; 9) részvételi karakter, amely a tevékenység különböző érintettjeinek bevonását jelenti.

A z EMES kritériumrendszere a társadalmi cél gazdasági-vállalkozói tevékenységbe ágyazottsága mellett hangsúlyozza a demokratikus irányítás szükségszerűségét. Ebben a megközelítésben az érintettek bevonása a döntéshozatalba, az autonóm müködés, a profitszétosztás korlátozása a biztosítékok arra, hogy a társadalmi cél elsőbbséget élvezzen az üzleti érdekek felett (Kiss 2015). Azaz a részvételi irányítás dimenzió definíciós 
kritériumként való megjelenítése a társadalmi dimenzió erősítését szolgálja, a demokratikus és autonóm, az érintettek részvételén alapuló működés teszi lehetővé a társadalmi célok prioritásának megőrzését az üzleti célokhoz képest.

A társadalmi vállalkozás fogalmának hazai értelmezéséhez jelentősen hozzájárult az Európai Unió operatív társadalmi vállalkozás definíciója, amely az SBI (Social Business Initiative) 2011-es meghatározásán alapul. Az SBI szerint a társadalmi vállalkozás olyan vállalkozás (EU Social Business Initiative 2011: 2; Kiss-Mibály 2019: 26):

- amelynek elsődleges célja a társadalmi hatás elérése, gyakran a társadalmi innováció magas szintje mellett;

- amelynek nyereségét elsősorban e társadalmi célok elérése érdekében forgatják vissza;

- amely felelősségteljes, átlátható és innovatív módon irányított, különösen az üzleti tevékenység által érintett munkavállalók, ügyfelek és érdekelt felek bevonása révén.

Ez a meghatározás - az EMES definíciójához hasonlóan - három dimenzió mentén értelmezi a társadalmi vállalkozásokat: a társadalmi, a gazdasági és az irányítási kategóriák jelennek meg itt is. Az elmúlt években mind az Európai Unióban, mind a Strukturális Alapok társfinanszírozásában Magyarországon is elérhetőek olyan pályázati források, amelyek kifejezetten a társadalmi vállalkozásoknak szólnak, vagy az őket támogató szervezetek és rendszerek fejlesztését célozzák. Ezek a felhívások a társadalmi vállalkozások körének meghatározásakor az SBI fenti, 2011-es definícióját hivatkozzák (Kiss-Mibály 2019).

A társadalmi vállalkozásokat több szerző is bibrid szervezeteknek tekinti, amelyek kombinálják több szektor jellemzőit (Battilana et al. 2015; Billis 2010). A társadalmigazdasági aktivitás formalizált tevékenységei három szektorban, az üzleti, az állami és a nonprofit szférában zajlanak. A három szektor megkülönböztetése a közgazdaságtanban a hetvenes évektől kezdve jellemző, akkoriban jelent meg ugyanis a makroökonómiában a nonprofit szféra tárgyalása a vállalatok (üzleti szektor) és az állam (közszektor) mellett (Antal et al. 2011).

$\mathrm{Az}$ üzleti szektor domináns koordinációs mechanizmusa a piac, tipikus szervezetei a profitorientált vállalatok, amelyek hosszú távú nyereség elérésére törekednek, ennek érdekében magánjavakat állítanak elő (kínálat) egyéni fogyasztói igények kielégítése (kereslet) céljából. A közszektor szervezetei kollektív igények kielégítése céljából müködnek, illetve a piaci kudarcok kezelése érdekében jöttek létre (Stiglitz 2000). E szektor domináns koordinációs mechanizmusa a redisztribúció, tipikus szervezetei a törvényhozó, végrehajtó és igazságszolgáltatási intézmények, valamint a piaci keretek között nem (hatékonyan) megvalósítható közcélokért, közszolgáltatásokért felelős szervezetek (pl. közoktatás, egészségügy stb). A nonprofit szektorba azok az intézményesült formában (formális keretek között) működő szervezetek sorolhatóak, amelyek az esetlegesen képződő nyereségüket nem osztják szét a tulajdonosok között, hanem teljes egészében visszaforgatják az alaptevékenységük finanszírozásába (profitszétosztás tilalma), továbbá a magánszférához tartoznak, azaz nem függnek közvetlenül a kormányzattól. Ezen túl jellemző e szervezeti körre a közjó/közérdek szolgálata, illetve az önkéntesség (SalamonSokolowski-List 2003).

Számos olyan szervezet létezik azonban, amelyek nem sorolhatóak be egyértelműen a fenti szektorok egyikébe, hanem müködésükben kombinálják, integrálják több szektor jellemzőit is. Ezeket a szervezeteket nevezi a szakirodalom szektorhatáron elhelyezkedő 
vagy hibrid szervezeteknek (Skelcher-Smith 2015). A társadalmi vállalkozásokat is hibrid szervezeteknek tekinthetjük, amelyek magukon viselik a nonprofit és az üzleti szektor, sőt bizonyos esetekben a közszektor jellemzőit is (Battilana-Lee 2014; Defourny-Nyssens 2012). Ebben a megközelítésben a felsőoktatási intézmények is hibrid szervezetek, főképp a vállalkozó egyetem koncepció, valamint a magánegyetemek értelmezhetők az üzleti és a közszektor határán elhelyezkedő intézményként.

Miképp a társadalmi vállalkozások meghatározásainak fenti áttekintése is mutatta, ez a szervezeti kör nagyon sokszínű, sokféle tevékenységet és társadalmi célt különböző szervezeti formában megvalósító szervezetet értünk e definíció alatt. Jaques Defourney és Marthe Nyssens 2016-os tanulmányukban emiatt a társadalmi vállalkozások kategorizálását javasolják, amely segíthet e diverzitás mélyebb megértésében és további kutatásában. A javasolt kategóriákat és helyüket a gazdasági-társadalmi szektorok kontextusában az 1. ábra mutatja.

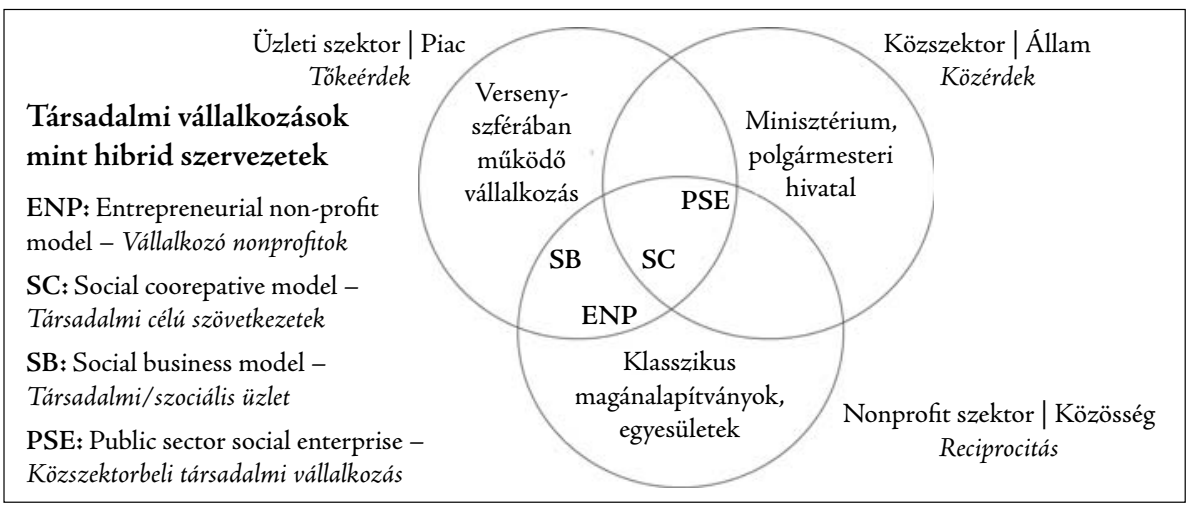

1. ábra: A társadalmi vállalkozások mint hibrid szervezetek lehetséges kategóriái (Saját szerkesztés Defourny-Nyssens 2016 alapján)

A szerzőpáros négy társadalmi vállalkozás kategóriát javasolt, amelyeket röviden az alábbiakban foglalunk össze:

1. Vállalkozó nonprofit modell (ENP - Entrepreneurial non-profit): a nonprofit szektor azon szervezetei, amelyek piaci jövedelmet biztosító üzleti tevékenységet alakítanak ki, hogy ezáltal is támogassák társadalmi küldetésüket. Ez a típus a leggyakrabban előforduló modell mind nemzetközileg, mind Magyarországon: valamilyen társadalmi ügyet célzó klasszikus nonprofit szervezet (alapítvány, egyesület) kezd üzleti tevékenységbe így egészítve ki egyéb bevételeit (pl. pályázati forrásokat, adományokat) (Kiss-Mihály 2019). Az üzleti tevékenység és a társadalmi ügyet szolgáló alaptevékenység egymáshoz való viszonya többféle lehet. Sok esetben a társadalmi ügyhöz nem kapcsolódó üzleti tevékenységet végez a nonprofit szervezet (pl. meglevő, ám nem használt infrastruktúra bérbe adása), ennek egyetlen célja pluszforrás biztosítása a társadalmi misszióhoz. Vannak olyan esetek is, amikor az üzleti tevékenység szervesen kapcsolódik a társadalmi cél megvalósításához, például amikor a célcsoport (pl. fogyatékkal élők) foglalkoztatása fontos célkitüzése a szervezetnek. 
2. Társadalmi célú szövetkezet modellje (SC - social cooperative): A szövetkezetek a tagjaik érdekében müködő, a tagok által tulajdonolt és (demokratikusan) irányított szervezetek, ahol jellemzően az egy tag - egy szavazat szabály érvényesül a döntéshozatalban. A tagoktól elvárt a személyes közremüködés a szervezet tevékenységének megvalósításában. Egy szövetkezetet akkor értelmezhetünk társadalmi vállalkozásként, ha a tagjai érdekein túl (kölcsönös érdek) tágabb érintetti kör igényeinek, elvárásainak mentén müködik, azaz közérdekü, közcélú tevékenységet is végez. Magyarországon az önálló jogi formaként 2006 óta létező szociális szövetkezet áll ehhez az értelmezéshez közel.

3. Társadalmi/szociális üzlet modell (SB - social business): Ez a kategória azokat a vállalatokat tartalmazza, amelyek üzleti tevékenységüket valamely társadalmi küldetés megvalósítása érdekében végzik. Példa lehet ilyen típusú müködésre a fair trade vagy az idősellátás területén müködő vállalkozások esete. Ezek a szervezetek az eddig ismertetett modellekhez képest közelebb állnak az ideáltipikus üzleti szervezetekhez (pl. jogi formájuk valamilyen gazdasági társaság), ugyanakkor a közcélú tevékenység a termékelóállítás vagy szolgáltatásnyújtás integráns része, és ez biztosítja a társadalmi cél elsődlegességét, de legalábbis a kiegyensúlyozott kettős értékteremtést. Ez a modell a leginkább vitatott típusa a társadalmi vállalkozásoknak. Defourney és Nyssens (2016) szerint e kategóriánál például erős méretbeli korlátok érvényesek, azaz inkább KKV-k, kisebb családi vállalkozások esetén biztosítható a társadalmi ügyet szem előtt tartó üzleti tevékenység. Nagy tőkekoncentrációval és emiatt magas megtérülési elvárásokkal rendelkező nagyvállalatok esetén erősen vitatható a társadalmi ügy elsődlegességének biztosíthatósága.

4. Közszektorbeli társadalmi vállalkozás (PSE - public sector social enterprise): A számos ország közszektorára nagy hatást gyakorló New Public Management (NPM, Új Közmenedzsment) mozgalom kulcselemei közé tartozik az üzleti és nonprofit szervezetek bevonása a közfeladatok ellátásába (ezáltal hibrid megoldások kialakítása), illetve a piaci mechanizmusok széles körü alkalmazása (pl. kötelező versenyeztetés) (Hajnal 2004; Pollitt 2003; Rosta 2012). A közfeladatok ellátásába pl. kiszervezés útján bevont üzleti vagy nonprofit szervezetek jellemzően erős kormányzati kontroll alatt maradnak, vagy legalábbis szigorú szabályozás jellemzi az ilyen típusú feladatellátást. A társadalmi vállalkozások ezen modelljénél a közszolgáltatások javítása, innovációja jellemzően fontos célkitűzés, ugyanakkor markánsan megjelenik a kisebb állam és a közfinanszírozás jelentős csökkentésének igénye is.

A társadalmi vállalkozások fenti modelljei megerősítik azt a cikkünk elején is hangsúlyozott állítást, miszerint a társadalmi vállalkozások rendkívül sokfélék. Az, hogy egy társadalmi vállalkozásnak milyen a közcélok iránti orientációja, miképp egyensúlyoz társadalmi és gazdasági célok között, milyen jogi formában működik és milyen erőforráskombinációval dolgozik stb., a fenti térképen számos pozíciót eredményezhet számára.

A társadalmi vállalkozások koncepcióját bemutató fejezet zárásaként röviden bemutatunk néhány - az oktatás területén működő - hazai társadalmi vállalkozást. $\mathrm{A} z$ Ashoka által támogatott társadalmi vállalkozások között az oktatás különböző szintjein találunk jó példákat: óvodáskorú gyermekek komplex személyiségfejlesztését és az esélyteremtést célozza a Blum-program (http://blumprogram.hu), a krónikus sze- 
génység kezelését és a szegregátumokban élő családok integrálódását egy komplex esélyteremtő programmal segíti az Igazgyöngy Alapítvány (https://igazgyongyalapitvany. hu/), amely többek között alapfokú müvészeti iskolát és a helyieknek munkahelyet adó vállalkozást is müködtet. Társadalmi vállalkozásként értelmezhető a Belvárosi Tanoda Alapítvány is (https://www.btabp.hu/), amely lemorzsolódó, kallódó, középfokú oktatásból kimaradt fiatalok támogatását célozza egy komplex befogadó programmal. A fenti példák mindegyike a vállalkozó nonprofit (ENP) modellhez sorolható, müködésükben fontos elem - az Ashoka társadalmi vállalkozó értelmezésének megfelelően - a társadalmi innováció és a változás elérése a megcélzott küldetés kapcsán. Üzleti modelljük a piaci jövedelemre úgy tekint, mint a társadalmi misszió megvalósítását támogató forrásra, azaz a társadalmi hatás elérése egyértelmủ prioritást élvez az üzleti tevékenységhez képest.

\section{A társadalmi vállalkozás koncepció értelmezése a felsőoktatási intézményekben}

A társadalmi vállalkozások és a felsőoktatási intézmények is szektorhatáron elhelyezkedő, hibrid szervezetként értelmezhetők. Ám amíg a társadalmi vállalkozások jellemzően a nonprofit szféra és az üzleti szektor metszetében helyezkednek el, addig a - hazai felsőoktatási intézmények, amelyek hagyományosan állami tulajdonban vannak, jórészt állami forrásból finanszírozottak és költségvetési intézményként müködnek, azaz alapvetően a közszektor részének tekinthetők. Ugyanakkor az elmúlt években a felsőoktatás környezetének átalakulásával és a vállalkozói egyetem koncepció terjedésével, a magánegyetemek és részben ez egyházi fenntartású intézmények megjelenésével az üzleti szektort jellemző vonásokkal gazdagodtak. Ilyen például a piaci bevételek arányának növelése szolgáltatások, technológiák értékesítésével, a menedzsment szerepének felértékelődése, piaci elvek, például versenyeztetés alkalmazása stb. Ezek a tendenciák a felsőoktatási intézményeket a köz- és az üzleti szektor határán értelmezhető hibrid szervezetekké tették. A felsőoktatási intézményekkel szemben egyre erőteljesebb elvárásként jelentkezik a harmadik misszió, a társadalmi felelősségvállalás erősítése, a helyi közösség szolgálata, amely a harmadik (nonprofit) szektort jellemző vonásokkal gazdagíthatja a képet.

Felmerül a kérdés, hogy a felsőoktatási intézmények értelmezhetők-e társadalmi vállalkozásként? E kérdés megválaszolása nem egyszerü, én nem is vállalkozunk az egyértelmü igen vagy nem álláspont elfoglalására. Ugyanakkor néhány további kérdés és dilemma felvillantása közelebb vihet minket a lehetséges kapcsolódások feltárásához. Visszatérve a különböző szektorok működési logikáira, és a közöttük levő határok elhalványulásának tendenciájára, láthattunk példákat olyan társadalmi vállalkozásokra, amelyek a három szektor metszetében léteznek, azaz magukon viselik a köz-, az üzleti és a nonprofit szektor jellemzőit is. Ezek a társadalmi célú szövetkezetek (social cooperatives), illetve a közszektorbeli társadalmi vállalkozások (public sector social enterprises). Amennyiben a felsőoktatási intézmények müködésében értelmezhetők a nonprofit szektort jellemző vonások, amelyek fontos jellemzői a társadalmi vállalkozásoknak, úgy - legalábbis koncepcionálisan - a felsőoktatási intézmények interpretálhatók társadalmi vállalkozási keretben. Ugyanakkor a vállalkozó egyetem koncepció kritikái éppen arra irányulnak, hogy az üzleti elvek megjelenése, a menedzserizmus erősödése az egyetemeket hagyományosan jellemző, a belső érintettek erős bevonására építő demokratikus és decentralizált irányítás fórumait szüntetik meg vagy épp teszik súlytalanná. A kép persze nem 
teljesen egyértelmű, hiszen a vállalkozó egyetem egyúttal a külső érintettek felé nyitott, őket megszólító, bevonó jellegű, de a szervezet irányításának részvételi jellege és átláthatósága, ahol mind a külső, mind a belső érintettek fontos szerepet kapnak a döntéshozatalban és az ellenőrzésben, kulcseleme a társadalmi vállalkozás koncepciónak (lásd EMES és SBI meghatározásait). Ezen a ponton érdekes lehet Defourny és Nyssens (2016) társadalmi vállalkozás tipológiájának felidézése, amely a lehetséges célok, működési módok, finanszírozási források különböző együttállásának lehetőségét hangsúlyozza. Ez a sokszínűség ugyanakkor azt is megmutatja, hogy a társadalmi cél elsődlegessége vagy legalábbis egyenrangúsága megvalósítható más (üzleti) célok egyidejű jelenléte mellett.

Fontos abból a szempontból is vizsgálni a kérdést, hogy a felsőoktatási intézményeknek célja-e, hogy önmagukra társadalmi vállalkozásként tekintsenek. E cikk írása kapcsán áttekintettük a felsőoktatási intézményekkel és a társadalmi vállalkozásokkal együtt foglalkozó nemzetközi publikációkat, és megállapítható, hogy nagyon csekély számban születtek ilyen témában kutatások, cikkek. A tématerület megjelenéséről a felsőoktatási intézmények oktatási tevékenységében több publikáció is született (Huq-Gilbert 2013; Patterson-Loomis 2007), amelyek főként azzal a fókusszal vizsgálódnak, hogy a társadalmi vállalkozás mint téma oktatása milyen módszertan és milyen kompetenciák fejlesztését eredményezi. Ugyanakkor a koncepció és a felsőoktatási intézmények működésének összekapcsolásáról csupán két cikket találtunk (Hoefer-Sliva 2016; Păunescu et al. 2013).

Hoefer és Sliva 2016-ban publikált cikkükben arra a következtetésre jutnak, hogy a felsőoktatási környezet potenciálisan alkalmas a társadalmi vállalkozási koncepció alkalmazására, hiszen a felsőoktatási intézmények társadalmilag hasznos tevékenységet végeznek, árbevételt generálnak piaci mechanizmusok alkalmazásával, a képződő profitot teljesen (de legalábbis jó részben) visszaforgatják a társadalmi küldetés érdekében, és a célcsoportjukat megerősítik, képessé teszik saját életük javítására fenntartható megoldások segítségével. A szerzőpáros a társadalmi vállalkozások társadalmi és üzleti dimenzióját hangsúlyozza, és nem reflektál a részvételi irányításra, illetve a társadalmi innováció szempontjára. Mi ezeket a jellemzőket is a társadalmi vállalkozások lényegi elemének tekintjük. Csupán az üzleti és a társadalmi dimenzió kiegyensúlyozottsága alapján definiált koncepció nagyon tágra nyitja és felhígítja a fogalmat, és ezáltal például nehezen teszi megkülönböztethetővé a vállalatok társadalmi felelősségvállalási (CSR) kezdeményezéseitől.

Păunescu és szerzőtársai 2013-as cikkükben a vállalkozó egyetem koncepcióját gondolják tovább, és teszik fel azt a kérdést, hogy hogyan kapcsolható össze a társadalmi vállalkozás koncepciója és az egyetemi müködés, illetve milyen mechanizmusok támogathatják a társadalmi vállalkozási orientációját az egyetemeknek. A szerzők megállapítják, hogy a felsőoktatásnak vannak jó eszközei, hogy a változást hozó vezetők jövendő generációit formálják, akik aztán képesek lesznek hatékonyabb megoldásokat találni a legsürgetőbb társadalmi problémáinkra. Ugyanakkor a felsőoktatási szektor társadalmi ügyekbe való bevonódása meglepően alacsony szintű és korlátozott hatású. Számos tudományterületen az egyetemi tantervek nem (vagy csak elvétve) tartalmazzák a felelősségvállalás kérdését, és nem tanítják a hallgatóknak azt, hogy a saját szakmájuk miképp járulhat hozzá egy jobb világhoz. Azonosítanak néhány lehetséges mechanizmust, gyakorlatot, amely a társadalmi vállalkozási orientációt erősítheti a felsőoktatási intézményekben: 
- Nagy szerepük van azoknak az oktatóknak, kutatóknak, akik egyúttal akadémiai hátterủ társadalmi vállalkozók, és tevékenységük jelentősen megváltoztat(hat)ja a gondolkodásmódot, illetve alakít(hat)ja a felelősségteljes viselkedést az egyetemeken.

- A társadalmi vállalkozói orientáció erősítését jelentheti a megoldatlan társadalmi problémákra való érzékenység és válaszkeresés az egyetemeken, például az oktatáshoz való hozzáférés szélesítésével vagy az oktatás tartalmának átalakításával.

- Az egyetemek hozzájárulhatnak a közös értékteremtéshez a helyi közösségekkel kialakított partnerségek révén.

Mivel azonban a hazai felsőoktatási intézmények egészét nem társadalmi vállalkozásként kezeljük, és önmagukat sem ebben az értelmezési keretben képzelik el, ezért érdemes áttekinteni azt, hogy a társadalmi vállalkozás mint tématerület, milyen módokon, fórumokon jelenik meg az egyetemeken. A következő két fejezetben erre a kérdésre keresünk választ.

\section{Társadalmi vállalkozások a hazai gazdálkodástudományi felsőoktatásban}

Jóllehet kifejezetten társadalmi vállalkozásoknak szentelt kurzust gazdálkodástudományi egyetemi képzésben mindössze négy felsőoktatási intézményben találtunk, a témát tárgyaló tantárgyak és programok sora ezekkel nem ér véget. Egyrészt van ilyesfajta élet a gazdálkodástudományon túl, komplett mesterprogramokkal és tantárgyakkal, másrészt azon belül is léteznek olyan kurzusok, amelyek legalább részben társadalmi vállalkozásokról szólnak. E fejezetben összegezzük a kínálatot és három irányból ragadjuk meg a társadalmi vállalkozások oktatásának felsőoktatási hozzájárulását: a téma, az alkalmazott oktatási módszertan mellett az ezekből fakadó reflexió lehetőségére térünk ki.

Kiss és Mihály (2019) kutatása szerint három mesterszak kínál Magyarországon elmélyülést a társadalmi vállalkozásokhoz legközvetlenebből kapcsolódó területekbe, és így maguknak a vállalkozásoknak a világába is: a szociális munka és szolidáris gazdaság (Debreceni Egyetem), a közösségi és civil tanulmányok (ELTE), valamint a helyi és regionális fejlesztés (Miskolci Egyetem). A társadalmi vállalkozás tartalmú nyári egyetemek (Pécsi Tudományegyetem, CEU) mellett összetett kezdeményezés a Moholy-Nagy Müvészeti Egyetem EcoLab-ja, mely több programot, mühelyt (Felhőgyár, BódvaPack, Lenkeproject [MOME Ecolab é.n.]) indított. Ezekben művészeti, társadalmi és természettudományos területek oktatói és diákjai igyekeznek társadalmi problémákra megoldást találni például a social design módszerével, társadalmi vállalkozások születésénél is bábáskodva. Kurzusként - mégha Társadalmi felelösségvállalás címen is - ideidézendő kettő (Miskolci Egyetem Tanárképző Intézete, ELTE Állam- és Jogtudományi Kara), amelyek civil szervezetekkel és társadalmi vállalkozásokkal „történő valós együttműködésre [épülnek], valamint az ott szerzett tapasztalatok becsatornázására a saját tanulási folyamatba" (Galambos 2019).

Képzések és fejlesztések felsőoktatási intézményeken kívül is elérhetőek, elsősorban társadalmi vállalkozások létrehozásán és múködtetésén fáradozók számára. Számos fejlesztő, inkubáló, mentoráló szervezet kínál olyan folyamatokat a társadalmi vállalkozás különböző fázisaiban (az ötlet megszületése, üzleti modellezés, skálázás, hatásmérés stb.) 
lévők számára, ahol leggyakrabban gazdasági-üzleti tudással vértezik fel az aspiráns társadalmi vállalkozókat az üzleti terv írásától a vállalkozási folyamatok szervezésén keresztül a befektetőknek tartott pitchig és kommunikációig. Ezek sorába tartoznak az ERSTE SEEDS programjai, az Impact HUB Social Impact Award folyamata, a Badur Alapítvány Keltető programja, ilyennel igyekszik felruházni tagjait és támogatott társadalmi vállalkozásait az Ashoka, a NESsT, sőt mentorporgramja keretében a hazai társadalmi vállalkozásokat EU strukturális alap forrásból támogató Piactárs GINOP program is. Ez a kínálat bizonyos értelemben a gazdálkodástudományi felsőoktatás társadalmi vállalkozás kurzusainak inverze. Üzleti-gazdasági tudást adnak társadalmi vállalkozásra specifikusan, jellemzően nem gazdasági háttérrel rendelkezőknek. A gazdálkodástudományi felsőoktatásban a másik oldalról érkezünk e terepre: üzleti tudással kistafírozott diákoknak mutatjuk meg a társadalmi vállalkozások alternatív világát.

Magyarországon 2006-ban indult az első Társadalmi vállalkozók tárgy a Budapesti Corvinus Egyetemen, több nyugat-európai és egyesült államokbeli kurzussal egy időben. Jelenleg emellett a Debreceni, a Miskolci és a Pannon Egyetemen tanítanak ilyen tárgyat „társadalmi vállalkozás” és „social startup” címeken. Ugyanakkor olyan oktatók gyakorlatát is ismerjük például a Budapesti Gazdasági Egyetemen és a Szegedi Tudományegyetemen, akik vagy vállalkozási tárgyak, mühelyek keretében mutatják be hallgatóiknak a társadalmi vállalkozásokat, vagy közösségi tanulási módszertant alkalmaznak, és ennek keretében kerülnek kapcsolatba a diákok társadalmi vállalkozásokkal.

Társadalmi vállalkozás érintőleges bemutatásával vagy teljes kurzusban történő elemzésével a felsőoktatásban új, ráadásul a gyakorlat által vezérelt téma jelenik meg: egyre erőteljesebben kutatott, ám nem az elméleti konstrukciók mentén létrejött terület. Hogy e tárgyak a gazdasági működésmód sokszínűségének egy újabb elemeként tárgyalják csupán a társadalmi vállalkozásokat, avagy a téma kritikai keretbe kerül, az a fellelt példákban erősen eltérő.

$\mathrm{A} z$ előbbi egyfajta szupermarket megközelitésként is leírható. Ez a hasonlat a vállalati társadalmi felelősségvállalás területéről ered, és azt kívánja kifejezni, hogy a vállalat a fogyasztók többféle szegmensét, köztük a felelős/etikus fogyasztásra törekvőket is szeretné elérni, éspedig oly módon, hogy számukra is kínál például környezetbarát termékeket, méltányos kereskedelem keretében elóállított és beszerzett cikkeket stb. Azaz portfóliójában tart a felelősségvállalás és ökológiai-társadalmi fenntarthatóság szempontjából jobb/megfelelő termékeket, ugyanakkor minden mást, ilyen pozitív jellemzőket nélkülöző, akár szennyező, problémás forrásból stb. származó árucikkeket is. Maga a vállalat (amely egyébként nem feltétlenül kiskereskedelmi cég, más vállalat is lehet, gyakori például befektetési alapkezelőknél, fenntartható, zöld és azon kívül is mindennemű részvényportfóliót kezelő alapokat kínálva) e szupermarket megközelítés mentén csak a fogyasztói igények kiszolgálása érdekében mutatkozik felelősségteljesnek a termékek egy korlátozott körében, ám teljes termékkörét és saját tevékenységeit, működési filozófiáját illetően korántsem. E hasonlatot a felsőoktatásra vonatkoztatva: társadalmi vállalkozás tárgyak létezhetnek csupán egy érdekes területként az oktatási kínálatban, a bemutatás szándékával, adott hallgatói kör igényeinek kielégítésére. Ám létezik a kurzusok normatív közelítésmódja is, kiindulópontként azt tartva szem előtt, hogy ha létezhet vállalkozási/vállalati működés, amely explicit módon létező társadalmi probléma megoldását célozza, akkor annak ezzel a normatív és társadalmi hatástöbblettel mintegy elsőbbséget szükséges élveznie, ráadásul puszta léte is tükre a gyakran éppen 
a vállalatok, gazdasági rendszerek indukálta társadalmi egyenlőtlenségeknek és ökológiai problémáknak. Egy, a társadalmi vállalkozások közelébe sorolt kanadai takarékszövetkezet reklámüzenetét hívva segítségül a gondolat megvilágítására: itt úgy tudsz befektetni, hogy „elérd a pénzügyi céljaidat és közben a közösségedet is szolgáld - miért is ne így akarna mindenki bankolni?” E szlogen nyilván nem normatív üzenetet kíván hirdetni, azt azonban megmutatja, hogy a gazdasági tevékenységben van értékválasztás.

Habár az áttekintett tantárgyak változatos pedagógiai alapokon nyugszanak és sokféle oktatásmódszertant alkalmaznak, a közösségi tanulás számos helyen képezi alapját a munkának. Együttmüködésen alapuló tapasztalati tanulás (Furco 1996) keretében a diák oly módon szerez (terepi) ismereteket, fejleszti képességeit, sajátítja el a tananyagot, hogy kurzusmunkájával - a társadalmi vállalkozóval együtt dolgozva - egyúttal társadalmi-ökológiai probléma megoldását segíti. Ez a módszertan javarészt éppen a társadalmi vállalkozások, nonprofit vállalkozások, civil szervetek révén ért el a felsőoktatásba: a velük való együttmüködés hozta be számos helyen a projekt- és/vagy problémaalapú oktatást, illetve lépett azon túl a közösségek bevonásán alapuló oktatás irányába. Ez utóbbit azonban már a következő fejezetben tárgyaljuk. Ezt a részt azzal zárjuk, hogy a társadalmi vállalkozás oktatás mind tartalmában, mind pedig módszerében kísérletet tehet érzékenyítésre társadalmi-ökológiai ügyek iránt, kritikai reflexióra többek között a piacgazdaság müködésére - és így a gazdálkodástudományi felsőoktatás tartalmára vonatkozóan -, alternatív gazdálkodási irányok és ezzel egyúttal a diákok számára alternatív karrierutak bemutatására.

\section{Társadalmi vállalkozások és a felsőoktatás harmadik missziója}

A közösségi tanulás, a közösségek bevonására alapuló oktatás és kutatás az alapfilozófiája az úgynevezett science shopnak, azaz - sohasem használt magyar fordításában - a tudományboltnak. Ezzel a névvel azokat a többnyire egyetemi, de akár egyetemen kívüli szervezeteket illetik, amelyek a társadalom tagjainak, aktív állampolgári csoportosulásoknak, civil szervezeteknek és társadalmi vállalkozásoknak a kérdéseit csatornázzák be az egyetemi oktatásba és kutatásba. Céljuk a nyitott tudomány és a nyitott egyetem megvalósítása. Az egyetemi tudás elérhetőségét nem csupán az eredmények szabad hozzáférhetőségével kívánják elérni, hanem az oktatásnak és kutatásnak közvetlenül a társadalom szükségleteire való formálásával, illetve ezen túlmenően azzal, hogy a kutatásba a társadalom tagjait tevékeny szereplőkként, társkutatókként, a közös alkotásba partnerekként vonják be. Azaz az „open science”, „citizen science” (lásd például Matolay et al. 2019) koncepcióira épít.

A magyarországi science shopok közül az egyetlen egyetemi szervezet, a Corvinus Science Shop példájával e cikkben azt mutatjuk be, hogy a társadalmi vállalkozásokkal való együttműködése mit nyújthat a felsőoktatásnak, az egyetemi érintetteknek. Jóllehet a science shop müködésében alapvető elem, hogy a kérdés, a felvetés a közösségi partnertől érkezzen - számára álljon nyitva és szabadon a lehetőség, hogy igényeit és kérdéseit az egyetemnek megfogalmazza -, ebben a cikkben, annak fókusza miatt, mégsem a közösségi partner igényeinek vagy éppen a közösségi partnerek körében generált társadalmi hatásnak az oldaláról közelítünk, hanem az oktatók-kutatók, a hallgatók és az egyetem mint intézmény javát szolgáló vonatkozásokat foglaljuk össze. 
A science shop egyik első megjelenése a Corvinuson az elmúlt időszak intézményfejlesztési terve volt, azaz megszületése előtt tulajdonképpen könnyedén testet öltött egy stratégiai dokumentumban, vélhetőleg azért, mert gyakorlatias módon látszik szolgálni a felsőoktatási intézmények harmadik misszióját. Ez utóbbi a „nem akadémiai világban található partnerrel fenntartott intézményesített kapcsolat" (Bángi-Magyar et al. 2010: 12) elsősorban gazdasági szereplőket és közintézményeket célzó tudástranszferként, valamint a felsőoktatási intézmény környezetében társadalmi felelősségvállalásként fogalmazódik meg. A science shop ténylegesen és közvetlenül együttmüködik külső egyetemi érintettekkel és a tudás megosztásáért dolgozik. Fókusza ugyanakkor nem vállalati, illetve közintézményi, hanem az egyetemi külső érintetti palettát további, társadalmi szereplőkkel gazdagítja. A tudástranszfert pedig olyan módon ragadja meg, hogy az nem csupán és nem elsősorban a tudományos eredmények hasznosítható kommunikációja, hanem - a tudományos és nem tudományos tudás egyenértéküségét vallva - a közösségi alapú oktatást és kutatást közös alkotásként (co-creation) fogja fel, s ezzel a tudástranszfert legalábbis kétirányúvá teszi, a tudomány és a társadalom párbeszédét erősíti. Mindezt pedig nem elkülönülten, hanem a felsőoktatás többi missziójával - oktatással és kutatással - integráltan teszi, a közösségbe ágyazott kutatás és tanulás (community engaged research and learning) mentén kurzusprojektekben, szakdolgozatokban, TDKkban és kutatásokban valósítja meg.

A misszióktól a science shop társadalmi vállalkozókkal folytatott munkájának a hétköznapi gyakorlatába lépve tovább a fő belső érintettek számára kínált alapvető előnyöket foglalja össze az 1. táblázat.

1. táblázat: A science shop által teremtett értékek az egyetem egésze és a fóbb belső értintettek szempontjából

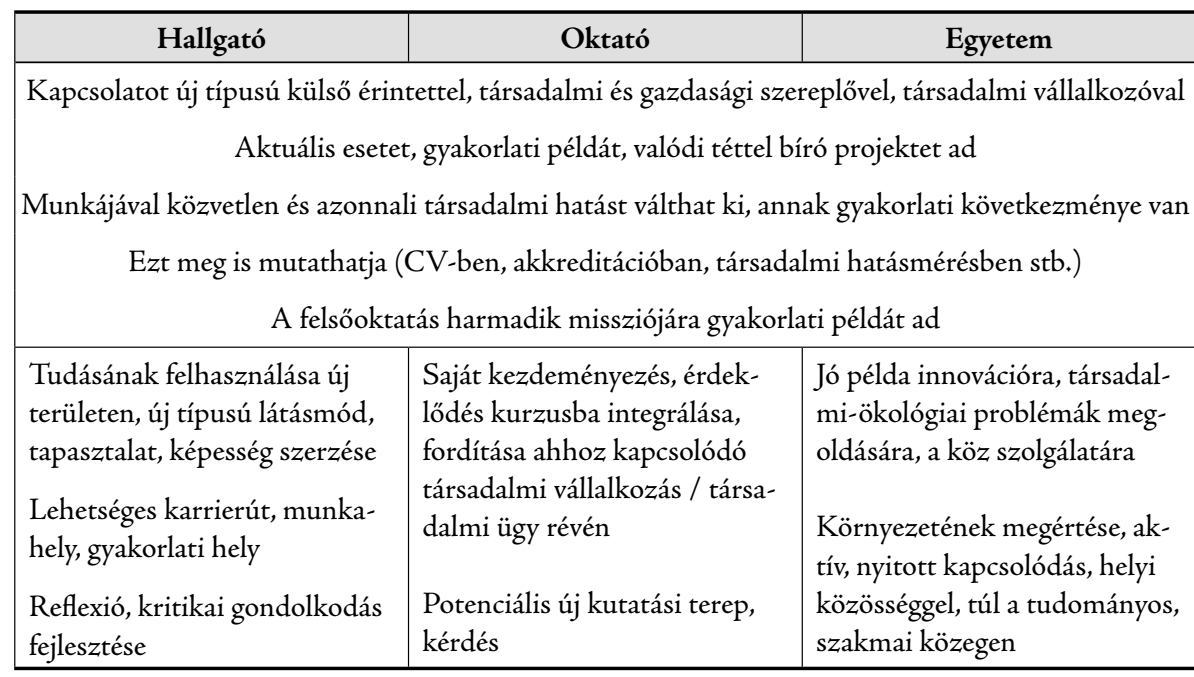

E praktikus előnyök tényleges megvalósulását egyelőre részlegesen tudta megragadni a szervezet, jelenleg output adatokkal rendelkezik, miszerint működésének első két tanévében 40 közösségi partner 76 kérdésére keresett választ 765 hallgató 29 oktató kurzusaiban. 


\section{Záró gondolatok, dilemmák}

Cikkünkben a társadalmi vállalkozás koncepció értelmezéseit és e szervezeti kör sokszínűségének felvillantását követően a felsőoktatási intézmények és a társadalmi vállalkozások lehetséges kapcsolódásait vizsgáltuk több szempontból is. Elsőként azt a kérdést feszegettük, hogy a társadalmi vállalkozások jellemzői mennyiben érvényesek a felsőoktatási intézmények működésében, azaz értelmezhetők-e az egyetemek társadalmi vállalkozási keretben. Egyértelmű válaszok helyett sokkal inkább további dilemmákat azonosítottunk e kérdés kapcsán. Bár mindkét intézmény hibrid szervezetként értelmezhető, és működésükben megjelennek a társadalmi és az üzleti célok is, valamint a felsőoktatási intézmények társadalmi felelősségvállalása erősödik, mégsem jelenthető ki egyértelműen, hogy az egyetemi működés egésze társadalmi vállalkozási keretben értelmezhető. Fontos dilemma az autonóm és részvételi irányítás kritériumának érvényesülése. A vállalkozó egyetemek esetében épp az irányítás demokratikus, a belső érintettekre erősen építő részvételi jellege alakul át a menedzserizmus megjelenésével. A külső érintettek bevonása sokszor csak szimbolikus. A társadalmi vállalkozások elsősorban alulról jövő kezdeményezésekből alakulnak, a helyi közösség problémáinak innovatív megoldása érdekében működnek, az általuk képviselt társadalmi ügyek közösségi beágyazódása jellemzően erős. Mindenképp fontos szempont tehát a vállalt társadalmi célok további elemzése a felsőoktatás esetében, annak a kérdésnek a vizsgálata, hogy milyen társadalmi célok, ügyek és hogyan jelennek meg az egyetemek esetében, és milyen módon jelenik meg a társadalmi innováció. Miképp a társadalmi vállalkozások, úgy az egyetemek is rendkívül sokfélék. A társadalmi vállalkozások bemutatott kategorizálása, illetve annak szempontrendszere érdekes lehet a felsőoktatási intézmények esetében is.

$\mathrm{A} z$ mindenesetre biztosan megállapítható, hogy jelenleg a hazai egyetemek nem értelmezik saját működésüket társadalmi vállalkozási keretben, még csak az sem merül fel, hogy beszállítóik körében társadalmi vállalkozásokat foglalkoztassanak. Éppen ezért azt is megvizsgáltuk, hogy e tématerület hogyan jelenik meg a hazai felsőoktatás oktatási portfóliójában. Röviden bemutattuk azokat a képzéseket és kurzusokat, amelyek keretében a társadalmi vállalkozások témakör hangsúlyosan megtalálható, illetve az egyetemek harmadik missziójához kapcsolódóan a science shop koncepciót ismertettük. E fejezetek kapcsán az a kérdés merül fel a jövőre vonatkozóan, hogy a társadalmi vállalkozás mint témakör megjelenése az oktatásban, kutatásban és egyéb fórumokon erősíti-e az egész egyetem társadalmi vállalkozás jellegét, vagy ellenkezőleg: a tématerület még az oktatási missziójában is parciális marad.

\section{IRODALOM}

Antal Z., Drótos G., Kiss N., Kováts G., Révész É. \& Varga-Polyák C. (2011) Közszolgálati szervezetek vezetése. Aula Kiadó, Budapest.

Bángi-Magyar A., Farkas, K., Horváth, T. \& Kiss, L. (2010) AVIR kézikönyv stratégiaalkotás, VIR, stratégiai mutató, adattár, felsőoktatási menedzsment. Educatio Társadalmi Szolgáltató Nonprofit Kft. https://www.felvi.hu/pub_bin/dload/AVIR_kezikonyv/ AVIR_kezikonyv_Teljes.pdf. [Letöltve: 2019.12.07.]

Battilana, Julie \& Lee, M. (2014) Advancing Research on Hybrid Organizing - Insights from the Study of Social Enterprises. The Academy of Management Annals, Vol. 8. No. 1. pp. 397-441. https://doi.org/10.1080/19416520.2014.893615. 
Battilana, J., Sengul, M., Pache, A.-C. \& Model, J. (2015) Harnessing Productive Tensions in Hybrid Organizations: The Case of Work Integration Social Enterprises. Academy of Management Journal, Vol. 58. No. 6. pp. 1658-1685. https://doi. org/10.5465/amj.2013.0903.

Billis, D. (2010, ed.) Hybrid Organizations and the Third Sector: Challenges for Practice, Theory and Policy. London, Palgrave Macmillan.

Defourny, J. \& Nyssens, M. (2012) The EMES Approach of Social Enterprise in a Comparative Perspective (WP no. 12/03; EMES Working Papers Series). EMES European Research Network.

Defourny, J. \& Nyssens, M. (2016) Fundamentals for an International Typology of Social Enterprise Models (ICSEM Working Papers No. 33; The International Comparative Social Enterprise Models [ICSEM] Project). http://www.iap-socent.be/sites/default/ files/Typology\%20-\%20Defourny\%20\%26\%20Nyssens.pdf. [Letöltve: 2019. 04. 09.]

EU Social Business Initiative (2011) Pub. L. No. COM 682 https://ec.europa.eu/ transparency/regdoc/rep/1/2011/EN/1-2011-682-EN-F1-1.Pdf [Letöltve: 2019. 10. 07.]

Furco, A. (1996) Service-Learning: A Balanced Approach to Experiential Education. In: Expanding Boundaries: Serving and Learning. Corporation for National Service. pp. 2-6.

Galambos, R. (2019) Egyetem a tudomány falain túl. https://i-dia.org/blog/egyetem-atudomany-falain-tul/ [Letöltve: 2019. 11. 03.]

Hajnal, G. (2004) Igazgatási reformok és New Public Management reformok egy összehasonlitó esettanulmány tükrében. Budapest, Budapesti Közgazdaságtudományi és Âllamigazgatási Egyetem.

Hoefer, R. A. \& Sliva, S. M. (2016) Social Enterprise in Higher Education: A Viable Venture? Journal of Social Work Education, Vol. 52. No. 4. pp. 422-433. https://doi.org/ 10.1080/10437797.2016.1165156.

Huq, A. \& Gilbert, D. H. (2013) Enhancing Graduate Employability through Work-based Learning in Social Entrepreneurship: A Case Study. Education + Training, Vol. 55. No. 6. pp. 550-572. https://doi.org/10.1108/ET-04-2012-0047.

KIss, J. (2015) Társadalmi célok, gazdasági tevékenységek - a társadalmi vállalkozások definíciói. Civil Szemle, Vol. 12. No. 1. pp. 5-23.

Kiss, J. \& Miнály, M. (2019) Társadalmi vállalkozások és ökoszisztémáik Európában. Magyar országjelentés. Európai Bizottság. http://unipub.lib.uni-corvinus.hu/4246/ [Letöltve: 2019. 09. 30.]

Matolay, R., Martoni, A., Gáspár, J. \& Toarniczky, A. (2019) Corvinus Science Shop, 2017/2018, 2018/2019 tanév; A Corvinus Science Shop jelentése. Budapest, Budapesti Corvinus Egyetem.

MOME Ecolab. (é. n.) MOME Ecolab a Moboly-Nagy Müvészeti Egyetem fenntarthatósági kutatócsoportja. https://momeecolab.wordpress.com. [Letöltve: 2019. 10. 14.]

Patterson, J. A. \& Loomis, C. (2007) Combining Service-Learning and Social Enterprise in Higher Education to Achieve Academic Learning, Business Skills Development, Citizenship Education, and Volunteerism. In: A. Campell \& L. Norton (eds) Learning, Teaching, and Assessing in Higher Education. Exeter, Learning Matters Ltd. pp. 120-135.

Păunescu, C., Drăgan, D., Cantaragiu, R. \& Filculescu, A. (2013) Towards a Conceptualization of Social Entrepreneurship in Higher Education. The International Journal of Management Science and Information Technology (IJMSIT), NAISIT Publishers, Toronto, Vol. II. No. 10. pp. 51-69.

Pollitt, C. (2003) The Essential Public Manager. Open University Press. 
Rosta, M. (2012) Az Új Közszolgálati Menedzsment intézményi meghatározottsága. Budapest, Budapesti Corvinus Egyetem.

Salamon, L. M., Sokolowski, S. W. \& List, R. (2003) Global Civil Society: An Overview (1. Aufl.). Baltimore, Johns Hopkins Center for Civil Society Studies.

Skelcher, C. \& Smith, S. R. (2015) Theorizing Hybridity: Institutional Logics, Complex Organizations, and Actor Identities: The Case of Nonprofits. Public Administration, Vol. 93. No. 2. pp. 433-448. https://doi.org/10.1111/padm.12105.

Stiglitz, J. E. (2000) A kormányzati szektor gazdaságtana. Budapest, KJK-KERSZÖV.

Tóth, L., VArga, É. \& VARga, P. (2011) A társadalmi vállalkozások helyzete Magyarországon 2011. NESsT.

A cikk a Creative Commons Attribution 4.0 International License (https://creativecommons.org/licenses/ by/4.0/) feltételei szerint publikált Open Access közlemény, melynek szellemében a cikk bármilyen médiumban szabadon felhasználható, megosztható és újraközölhető, feltéve, hogy az eredeti szerző és a közlés helye, illetve a CC License linkje és az esetlegesen végrehajtott módosítások feltüntetésre kerülnek. (SID_1) 